\title{
THE NEOTROPICAL SPECIES OF THE ANT GENUS STRUMIGENYS FR. SMITH: SYNOPSIS AND KEYS TO THE SPECIES ${ }^{1}$
}

\author{
By William L. Brown, JR. \\ Department of Entomology, Cornell University \\ Introduction
}

The New World Strumigenys have been revised through a series of twelve papers bearing the general foretitle, "The Neotropical species of the ant genus Strumigenys Fr. Smith," plus several articles by Dr. W. W. Kempf and by myself, beginning with my "Preliminary generic revision of the higher Dacetini" (Brown, I948). It now seems appropriate to offer a unifying synopsis of the New World species of the genus, along with keys for identification and some general remarks.

\section{Species Synopsis of New World Strumigenys}

The synopsis below includes the names, each with author and date of publication, plus citation of the principal references in the Brown or Kempf papers already mentioned, which are listed in the section of "References" at the end of this article. These papers contain references to original descriptive and distributional material for each species, but I have included in the synopsis new or supplementary information wherever it seemed useful to do so. The species are listed by groups in order of apparent relationship, as closely as it is possible to place them in a purely linear order. The probable relationships within the genus in the New World are discussed at the end of the synopsis. It will be noticed that the group placement of some species differs from that of the previous parts published. The present grouping represents a reconsideration of all of the New World species taken together.

\section{Group of mandibularis}

I. Strumigenys mandibularis Fr. Smith, I860

Brown, 1953b: 53-55, worker, synonymy.

Frederick Smith confused two species under this name; one of these was later described as $S$. prospiciens by Emery. In order to fix these names unambiguously according to present usage, I hereby designate as lectotype of $S$. mandibularis the worker in the British Museum (Natural History), which was called "holotype" in my 1953 paper.

\footnotetext{
${ }^{1}$ Published with the aid of a grant from the Grace Griswold Fund of the Department of Entomology, Cornell University.

Manuscript received by the editor January 25, 1962.
} 
Although this specimen is labeled as "type," Smith never designated a type in print, and at least some of his original specimens exist elsewhere (e.g., in the Munich Museum).

Distribution: Amazon Basin; known only from the type series.

Synonym: S. batesi Forel.

2. Strumigenys godmani Forel, 1899

Brown, 1953b: 55-56, worker, female, variation.

Biology: Lives in wet forest. The nest I found in Panama was in a small rotten $\log$ in cloud forest.

New records: Panama: Progreso, Chiriqui Prov. (F. M. Gaige leg.) ; Cerro Campana, about $950 \mathrm{~m}$ altitude, Panamá Prov. (W. L. Brown, Jr. leg.).

Distribution: Costa Rica, Panama, British Guiana.

Synonym: S. ferox Weber.

3. Strumigenys planeti Brown, I953

Brown, 1953b: 57-59, worker, female, variation, distribution.

Biology: Apparently a rain forest species. Weber (1952) reports a nest taken in a wet mossy $\log$ in a cacao plantation on Trinidad.

New record: Peru: Monson Valley, Tingo Maria, winged female (E. I. Schlinger and E. S. Ross leg.).

Distribution: Trinidad, Amazon Basin to Bolivia and Peru.

4. Strumigenys smithii Forel, I886

Brown, 1953c: 104-107, worker, variation, distribution, biology.

Biology: Nests in rotten logs, rotten twigs or, on St. Vincent, rarely in sod. Primarily a forest species.

New records: Colombia: Loma Larga, Sierra Santa Marta (F. M. Gaige leg.). Panama: Cerro Campana, $800 \mathrm{~m}$, Province of Panamá (G. B. Fairchild and W. L. Brown, Jr. leg.).

Distribution: Costa Rica south to Santa Catarina, Brazil, and Amazonian Bolivia; St. Vincent, B. W. I.

Synonym: S. smithi var. inaequalis Emery.

5. Strumigenys hemidisca Brown, 1953 (Fig. 22)

Brown, 1953c: 107-108, worker.

Biology: The type series came from orchid plants intercepted in U. S. plant quarantine, and so were probably nesting amid the epiphy-
tes in trees.

Distribution: Venezuela; known only from the type series.

6. Strumigenys prospiciens Emery, 1906

Brown, 1953c: 108-110, worker, female, distribution. 
Distribution: Amazon Basin south to Bolivia and to northern Argentina: Misiones.

7. Strumigenys biolleyi Forel, I908 (Fig. 28)

Brown, 1953c: 101-104, worker female, variation, distribution.

Biology: A forest species, nesting mainly in rotten logs.

New records: Ecuador: Io miles north of Manglar Alto, Guaymas

(E. I. Schlinger and E. S. Ross leg.). Panama: Cerro Campana, Panamá Prov., 800 m altitude (W. L. Brown, Jr. leg.).

Distribution: Southern Mexico (Chiapas) south through Central America to Ecuador.

Synonyms: S. tridens Weber, S. luctuosa Menozzi.

8. Strumigenys saliens Mayr, I 887

Brown, 1954b: 55-57, worker, female, distribution, biology.

Biology: Nests in rotten logs and branches lying on the floor of forest.

Distribution: Southeastern Brazil and northeastern Argentina: Misiones.

Synonyms: S. saliens var. procera Emery and var. angusticeps Forel.

9. Strumigenys borgmeieri Brown, I954

Brown, 1954b: 57-59, worker.

Distribution: Brazil: Pernambuco; known only from the holotype.

IO. Strumigenys trinidadensis Wheeler, I922 (Figs. I 4, 23)

Brown, 1954b: 59-62, worker, male, distribution.

New record: Esmeralda, Ecuador (J. Foerster leg.).

Distribution: Trinidad, northeastern Brazil, Ecuador, Amazonian Bolivia; probably widespread in the interior of South America.

I I. Strumigenys sanctipauli Kempf, I958 (Fig. 24)

Kempf, 1958b : 556-559, figs. 1-4, worker.

Distribution: Brazil: Serra do Mar, São Paulo State; known only from the holotype.

12. Strumigenys sublonga Brown, I958

Brown, 1958a: 221-222, fig. 1C, D, worker, female.

Distribution: Bolivia: Lower Rio Madidi; known only from type series.

13. Strumigenys rehi Forel, I907

Brown, 1958a: 222-223, worker.

Biology: This species was taken from orchid plants arriving at Hamburg, Germany, a circumstance agreeing with the large eyes of the worker to indicate an arboreal habitat. 
Distribution: Amazon Basin; exact type locality unknown.

I4. Strumigenys cordovensis Mayr, I887 (Figs. 25, 26, 27)

Brown, 1958a: 218-220, fig. 1B, E, F, G, worker, variation, distribution.

Distribution: Southern Mexico to Trinidad and the Guianas.

I 5. Strumigenys mokensis Forel, I905

Brown, 1958a: 221, raised from variety to provisional species rank.

This is a very doubtful form, most likely a synonym of cordovensis. The whereabouts of the type is unknown. The species is not included in the key.

Distribution: La Moka, Venezuela, type locality.

I6. Strumigenys dolichognatha Weber, 1934

Brown, 1958a:223-224, fig. 1A, worker.

Distribution: British Guiana: Kartabo; known only from the type series.

\section{Group of cultriger}

I 7. Strumigenys cultriger Mayr, I887 (Fig. 9)

Brown, 1957: 97-99, worker.

New record: X Xaxim, Santa Catarina (F. Plaumann leg.).

Distribution: Southeastern Brazil.

I8. Strumigenys deltisquama Brown, I957

Brown, 1957: 99-101, fig. 1a, b, worker.

Distribution: Panama Canal Zone: Barro Colorado Island; known from types only.

\section{Group of tococae}

I 9. Strumigenys tococae Wheeler, 1929

Brown, 1957: 101-102, fig. 1c, worker.

Biology: The types were taken from an abundant population inhabiting the foliar sacs of Tococa formicaria, a tall myrmecophytic shrub, in the outskirts of Bolém. From this circumstance and the large size of the eyes, $S$. tococae is judged to be an arboreal or subarboreal specialist.

Distribution: Belém, Brazil, at the mouth of the Amazon; known only from the type serics.

20. Strumigenys fairchildi Brown, I96I

Brown, 1961: 60-61, worker.

This species, described from a single worker, is very close to $S$. tococae, but differs markedly in gastric sculpture and pilosity. It is 
not known whether $S$. fairchildi lives in plant cavities, but it does seem likely that it is a subarboreal forager.

Distribution: Panama: Cerro Campana, Panamá Province ca. $800 \mathrm{~m}$ altitude; known only from the holotype.

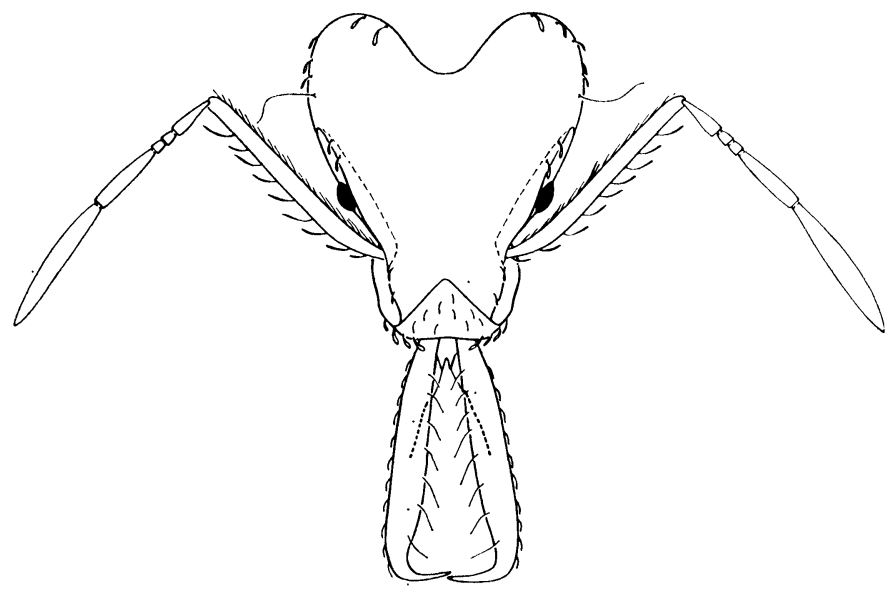

Figure 1. Strumigenys ludia, worker from Veracruz, dorsal full-face view of head showing fringing pilosity only.

\section{Group of ludia}

21. Strumigenys longispinosa Brown, I958

Brown, 1958b : 123-126, figs. 1, 2, worker.

Biology: Nests in the soil of tropical forest.

Distribution: Panama.

22. Strumigenys marginiventris Santschi, I93 I

Brown, 1958b : 126-128, fig. 3, worker, female.

Biology: Nests in the soil, often in paths or other other openings, in rain forest or plantations, and the workers forage over the open ground among leaves or herbs by day as well as night. Common on Barro Colorado Island.

New records: Palmar, Puntarenas Dept., Costa Rica, in soil of banana plantation, several collections (E. O. Wilson leg.).

Distribution: Golfo Dolce region of Costa Rica to northern Colombia.

23. Strumigenys ludia Mann, I922 (Figs. I, 5)

Brown, 1954a: 194-196, worker, female.

Biology: $S$. ludia has been investigated at length in the field by 
Wilson and in the artificial nest by Wilson and Brown, and the details will be published elsewhere. S. ludia is a forest species and usually nests in rotten branches or twigs lying on the forest floor. The food is chiefly entomobryoid Collembola caught alive in the manner usual for the genus.

New records: Mexico: Ridge between Antiguo Morelos and Nuevo Morelos (E. S. Ross leg.). Pueblo Nuevo, near Tetzonapa, Veracruz (E. O. Wilson leg.). Costa Rica: Abaca Plantation, Bataan (C. H. Batchelder).

Distribution: Southern Mexico to Costa Rica.

Synonym: S. ludia subsp. tenuis Weber.

\section{Group of hindenburgi}

24. Strumigenys hindenburgi Forel, I9I5 (Fig. 8)

Brown, 1961: 61-64, worker, pseudogyne, distribution.

Distribution: Northern Argentina extending into southeastern Brazil.

25. Strumigenys lanuginosa Wheeler, I905 (Fig. 4)

Brown, 1961: 61-63, worker, female, distribution.

Distribution: Southern Mexico, Panama; Bahamas, where probably introduced.

26. Strumigenys ogloblini Santschi, I936

Brown, 1958c: 136-137, fig. 1b, worker, female.

Distribution: Northern Argentina, probably also in southern Brazil.

\section{Group of elongata}

27. Strumigenys precava Brown, I954 (Fig. 7)

Brown, 1954a: 196-200, worker, female.

Biology: I found this species rather common on Barro Colorado Island in the Panama Canal Zone, nesting in red- or chocolate-rotten logs. One nest found was very large, containing several hundred perhaps a thousand or more - workers. Workers were seen carrying a mycetophilid larva and a termite nymph into this nest as it was being opened, and a captive colony fed on a wide variety of small arthropods, including entomobryoid collembolans.

New record: Panama: Cerro Campana, Panamá Province, about $800 \mathrm{~m}$ altitude, in a small rotten $\log$ in a cloud forest ravine, with winged females, Jan. I6, I96o (G. B. Fairchild and W. L. Brown, Jr. leg.). 

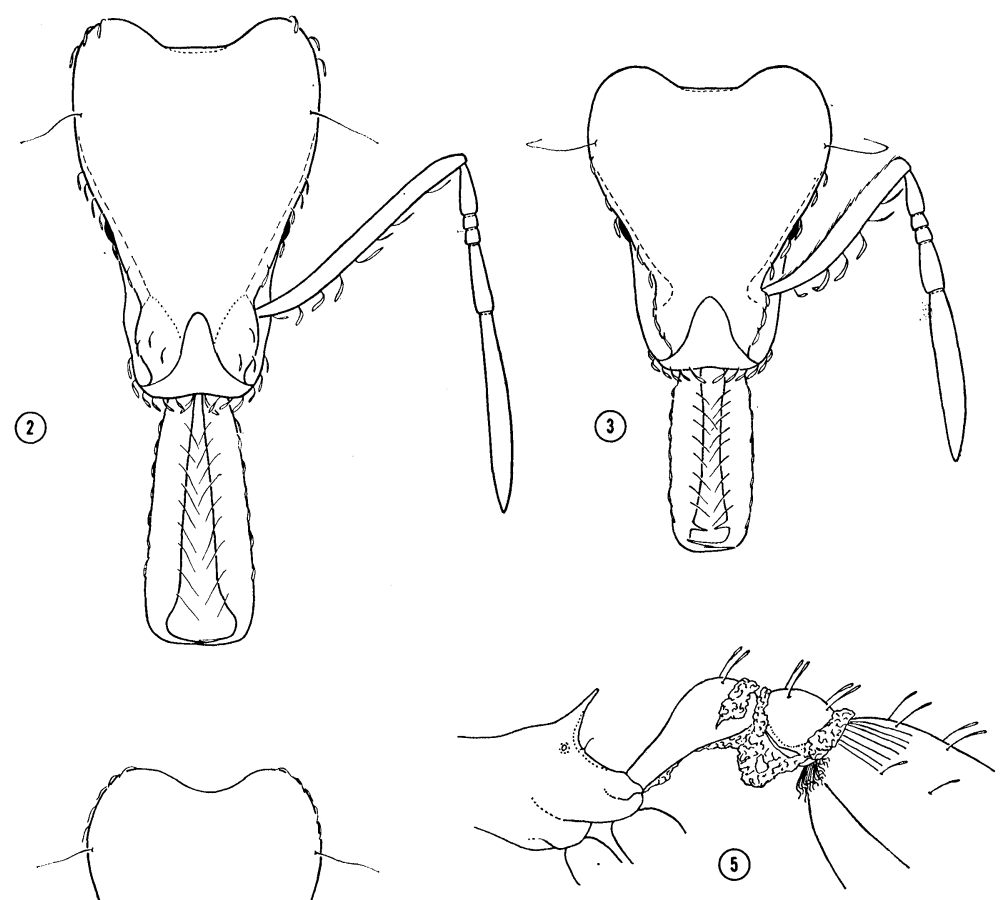

(4)
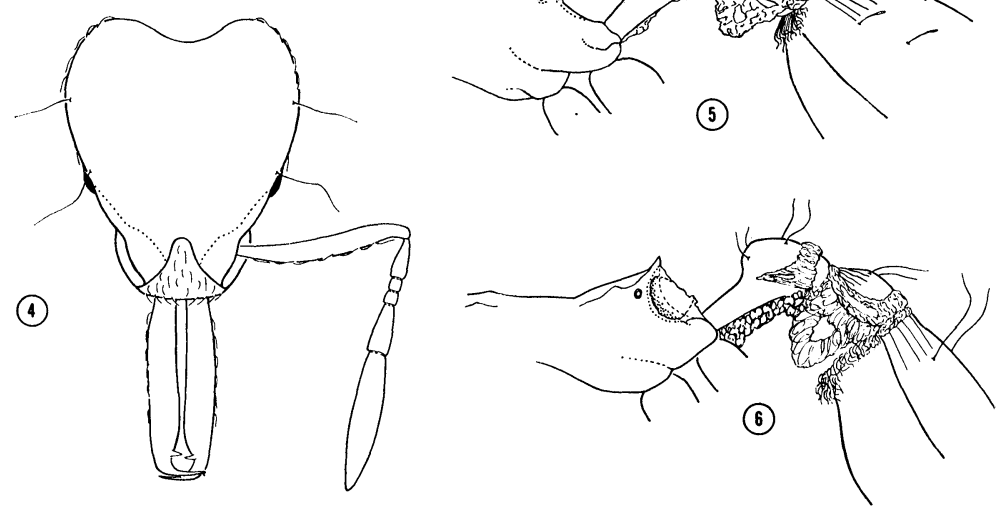

Figures 2-6. Strumigenys spp., workers. Figure 2, S. lacacoca, paratype, dorsal full-face view of head, showing fringing pilosity only. Figure $3, S$. nevermanni, same. Figure 4, S. lanuginosa, same. Figure 5. S. ludia, Veracruz, side view of posterior alitrunk, nodes and anterior part of gaster. Figure 6, S. lacacoca, paratype, same. Roughly to same scale. 
Distribution: Panama, British Guiana, Amazonian Bolivia; probably widespread in hylaean South America.

28. Strumigenys elongata Roger, I 863

Brown, 1954a: 189-192, worker, female, male, variation, synonymy, distribution, biology.

Biology: This species is definitely a collembolan feeder, common in the leaf litter of tropical forest. It scems to tolerate drier as well as wet forest types.

New records: Mexico: Pueblo Nuevo and El Palmar, near Tetzonapa, Veracruz (E. O. Wilson leg.). Ocosingo Valley, Chiapas (C. and M. Goodnight and L. Stannard leg.).

Distribution: Southern Mexico to Bolivia and southeastern Brazil.

Synonyms: S. imitator Mayr, S. elongata subsp. nicaraguensis Weber.

29. Strumigenys consanii Brown, I954

Brown, 1954a: 192-194, worker.

A larger, more robust relative of elongata with smooth and shining postpeticlar disc.

Distribution: Costa Rica: La Palma, near San José, I 500 m altitude; known only from the type series.

\section{Group of emeryi}

30. Strumigenys emeryi Mann, 1922

Brown, 1959a: 97-99, worker, variation, distribution.

Distribution: Honduras, southern Mexico.

3I. Strumigenys boneti Brown, I959 (Fig. I2)

Brown, 1959a: 103-104, worker.

Distribution: Southern Mexico.

32. Strumigenys nevermanni Brown, I959 (Fig. 3)

Brown, 1959a: 99-100, worker, female.

Distribution: Costa Rica: Hondura, I050 m altitude; known only from types.

33. Strumigenys micretes Brown, 1959 (Figs. I3, I9)

Brown, 1959a: 100-101, worker. Brown, 196: 58-60, variation, distribution.

As mentioned in the note in couplet 2I of the key (below), this species and $S$. lacacoca may actually represent different populations of the same species.

Biology: A specics of rain forest and cloud forest.

34. Strumigenys lacacoca Brown, I959 (Figs. 2,6) 
Brown, 1959a: 101-102, worker. Brown, 196: 58-60, worker variation, distribution.

Distribution: Central Panama.

\section{Group of silvestrii}

35. Strumigenys silvestrii Emery, I905 (Fig. I 8)

Brown, 1959c: 25-28, fig. 1, worker, female, synonymy, variation, distribution.

Distribution: Northern Argentina, southern Brazil; also in Cuba and Louisiana, U. S. A., where probably introduced by commerce.

Synonym: S. caribbea Weber.

36. Strumigenys carinithorax Borgmeier, I934

Brown, 1959c: 29-30, worker, female, male.

Distribution: Dutch Guiana: vicinity of Paramaribo.

37. Strumigenys schmalzi Emery, 1905

Brown, 1959c: 28-29, worker.

Distribution: Southeastern Brazil.

38. Strumigenys perparva Brown, 1958

Brown, 1958c: 133-135, fig. 1a, worker, female.

Distribution: Trinidad and the Guianas to São Paulo; probably interior Brazil.

\section{Group of louisianae}

39. Strumigenys mixta Brown, I953 (Figs. I 5, 2 I )

Brown, 1953a: 4-5, worker.

Biology: One of the two original series was taken in orchid plants at quarantine, so the species may be arboreal or subarboreal.

Distribution: Guatemala; known only from the types (two localities).

40. Strumigenys louisianae Roger, I 863

Brown, 1953a: 2-3, description of synonymous $S$. clasmospongia, worker.

Brown, 1953d: 28-31, figs. 1, 3, worker, variation, synonymy, distribution.

Brown, 1961: 64-68, geographical variation, synonymy.

Biology: The feeding habits of this species have been studied in some detail by Wilson (I950, I954) and by myself. The food consists of a variety of small arthropods found in and on the soil cover and caught by the workers with their trap-like jaws. The preferred prey are entomobryoid and symphypleonan Collembola; poduroid collembolans are not taken.

Distribution: Widespread in the Americas from Virginia and Tennessee south at least to the Tucumán area of Argentina; north- 
ward in Mexico to sheltered canyons and cultivated areas of southern Arizona; greater Antilles (except Jamaica). Unaccountably absent from certain well-collected areas within this range, such as parts of the Canal Zone, Trinidad and British Guiana, although plentiful in Costa Rica and at least some localities in Colombia. This species tolerates much drier conditions and will live in plantations and other cultivated situations, so perhaps it is found mostly in habitats outside the primary forest in the central parts of its range. Its range and ecological amplitude are greater than those of any other New World Strumigenys.

Synonyms: S. unidentata Mayr, S. unispinulosa Emery, S. unispinulosa var. longicornis Emery, S. fusca Emery, S. louisianae var. obscuriventris Wheeler, S. bruchi Forel, S. infidelis Santschi, S. eggersi var. cubaensis Mann, S. louisianae subspp. laticephala M. R. Smith, soledadensis Weber, guatemalensis Weber, and costaricensis Weber, $S$. clasmospongia Brown. The long list of synonyms reflects in part the rather extreme variation shown by this species on the South American continent. More peripheral populations (North and Central America, West Indies, Argentina) tend to be more uniform both within and among themselves.

\section{I. Strumigenys producta Brown, I953}

Brown, 1953 a : 3-4, worker.

This species is a larger, long-mandibulate version of $S$. louisianae. In view of the extensive variation now known for the latter species in South America, it would not be surprising to find that S. producta is just an extreme local variant of $S$. louisianae.

Distribution: Basin of the Rio Beni, Bolivia; known only from the types.

\section{Group of connectens}

42. Strumigenys connectens Kempf, I958 (Fig. I I)

Kempf, 1958a: 59-64, figs. 1-3, worker, variation.

Biology: The paratype series was taken in orchid plants in U. S. quarantine, so the species is presumably arboreal.

Distribution: The species is known from two localities, both in Colombia.

\section{Strumigenys laevipleura Kempf, 1958}

Kempf, 1958a: 64-65, figs. 5-7, worker.

Biology: Like $S$. connectens, this species was also taken from an orchid shipment, and it may therefore be arboreal in habits.

Distribution: Known only from the type series from Colombia, apparently from the vicinity of Medellin. 
44. Strumigenys xenognatha Kempf, 1958

Kempf, 1958a: 65-66, fig. 4, female.

Biology: The holotype female, a unique, was taken from orchid plants and bears the same data as the S. laevipleura types, from which it differs too widely to be their queen. Perhaps it is a social parasite of S. laevipleura.

Distribution: Colombia.

\section{Group of gundlachi}

45. Strumigenys subedentata Mayr, I 887

Brown, 1960: 48-50, figs. 7, 9, worker, female, male, variation, distribution, biology.

Biology: This species nests in small colonies in the soil or soil cover in mesic tropical forest and feeds chiefly on entomobryoid Collembola.

Distribution: Southern Mexico south to southeastern Brazil ; Trinidad; probably widespread in interior South America.

Synonyms: S. tristani Menozzi, $S$. clavata Weber.
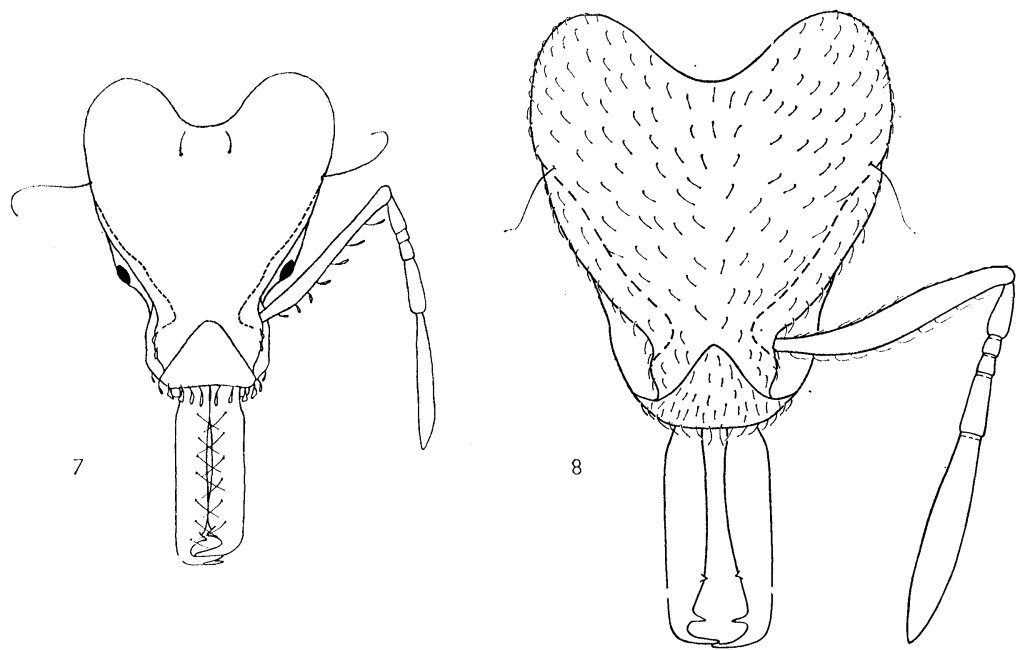

Figures 7-8. Strumigenys spp., workers, dorsal full-face view of head. Figure $7, S$. precava from Panama Canal Zone, showing fringing pilosity only. Figure 8, S. hindenburgi from Tucumán, Argentina. Not to same scale.

\section{Strumigenys trieces Brown, I960}

Brown, 1960: 50-51, fig. 8, worker.

Distribution: Costa Rica; known only from the holotype. 
47. Strumigenys denticulata Mayr, I 887

Brown, 1960: 47-48, fig. 3, worker, female.

Biology: Occurs in both primary and second-growth forest, in leaf litter; epiphytes and in termite nests.

Distribution: Trinidad and the Guianas south to southeastern Brazil ; probably occurs widely in interior South America as well.

48. Strumigenys jamaicensis Brown, I 959

Brown, 1959b: 6, worker. Brown, 1960: 45-46, fig. 4, worker.

Distribution: Mountains of Jamaica.

49. Strumigenys gundlachi (Roger, I 862)

Brown, 1960: 40-45, figs. 1, 5, worker, female, synonymy, distribution, biology.

In addition to the characters cited in the key, it may be mentioned that fully-colored $S$. gundlachi workers and females are usually darker in color (brownish-red to dark brown) than are those of $S$. eggersi (ferruginous yellow).

Biology: S. gundlachi feeds chiefly if not entirely on entomobryoid and sminthuroid Collembola, which it catches by employing a relatively inactive "ambush" type of hunting, but if the prey struggles after being struck, it may be lifted off the ground and stung in the manner of other Strumigenys. In many parts of the Caribbean countries, this is a very abundant ant in the leaf litter of tropical forest, thickets and plantations, and it tolerates a wide variety of ecological conditions.

Distribution: Central America and southern Mexico, southern Florida, West Indies to Trinidad.

Synonyms: S. eggersi varieties vincentensis Forel, banillensis Santschi, isthmica Santschi and berlesei Weber; S. eggersi subsp. infuscata Weber, and S. bierigi Santschi.

50. Strumigenys eggersi Emery, I 890 (Figs. IO, 20)

Brown, 1960:46-47, figs. 2, 6, worker, female, variation, distribution, biology.

Biology: Found in forests, thickets, gardens, etc. Almost certainly a collembolan feeder.

Distribution: Trinidad and the Guianas to southeastern Brazil and Amazonian Bolivia. Widespread (possibly by recent introduction) in the West Indies; southern Florida; southern Mexico.

\section{Group of rogeri}

51. Strumigenys rogeri Emery, I 890 (Figs. I6, I 7, 29)

Brown, 1954, Bull. Mus. Comp. Zool., 112: 20-23, worker, female, feeding habits.

Although $S$. rogeri was first described from West Indian material, I 
showed in 1954 that it is a tramp belonging to a characteristically African species-group, and itself probably West African in origin.

Distribution: Widespread in the West Indies, from Cuba to Trinidad; British Guiana; West Africa; Hawaii, Tahiti, Fiji, Micronesia; greenhouses in England and Scotland; apparently spreading rapidly through commerce.

Synonyms: S. incisa Godfrey, S. sulfurea Santschi.

\section{Phylogeny of the New World Strumigenys}

I belong to the school that believes that since Darwin phylogenetic reasoning is inseparably a part of the taxonomic ordering of any group. The work of the more outspoken "aphyletic taxonomists" shows that they have not escaped the influence of evolutionary thinking, either, when it comes to revising a species-group or genus or family. Phylogenetic thinking is usually more or less implicit in the grouping of species, as I have grouped the New World species (above). In Figure 30 I have shown my best guess as to how the species groups are related one to the others. This diagram should not be taken too seriously, because Strumigenys species are very likely to be convergent from different groups, and the convergence may be very close and may involve several to many characters.

The most serious problem in Strumigenys is the question of direction of evolution; in other words, which species or groups are primitive, and which derived? One can look to the other two faunas of the genus (Ethiopian-Malagasy and Indo-Australian), but these give little help at present. I used to think, for no very good reason, I suppose, that certain species with large, ruggedly modelled heads and heavy, more or less closely approximate mandibles [chyzeri group of Melanesia,

Explanation of Plate 18

Figures 9-29. Strumigenys spp., workers. Figures 9-12 and 14-16 show left mandibles in dorsal view; Figure 13 is a dorsal enlarged view of the apices of both mandibles. Figure 9, $S$. cultriger. Figure 10, $S$. eggersi. Figure 11, $S$. connectens, paratype. Figure $12, S$. boneti, paratype. Figure $13, S$. sp. near micretes from Boquete, Panama - one of several variants from this locality. Figure 14, $S$. trinidadensis. Figure 15, S. mixta, paratype. Figure 16, S. rogeri. Figures 17-21 are end-on views of the apical fork of the mandibles, much enlarged. Figure 17, S. rogeri. Figure 18, S. silvestrii. Figure 19, S. micretes, paratype. Figure 20,S.eggersi. Figure 21, $S$. mixta, paratype. Figures 22-28, lateral view of propodeal lamella. Figure 22, $S$. hemidisca, holotype. Figure 23, S. trinidadensis, paratype. Figure 24, S. sanctipauli, holotype after Kempf. Figure $25, S$. cordovensis. Figures 26,27 , same, showing extremes of variation in different individuals; the pattern of Figure 27 is common in southern Mexico. Figure 28, S. biolleyi. Figure 29, S. rogeri, left side of head near eye as seen from dorsal full-face view, to show "detached" eye. 

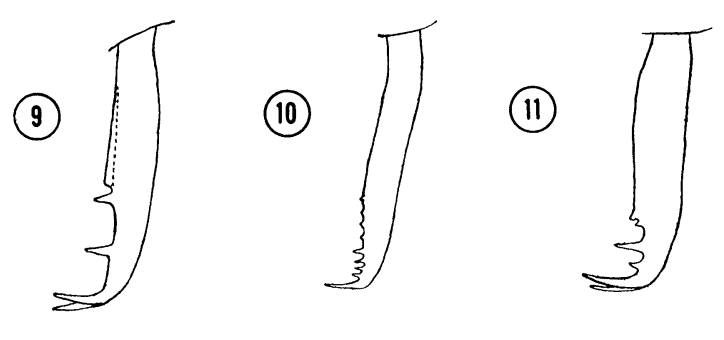

(12)
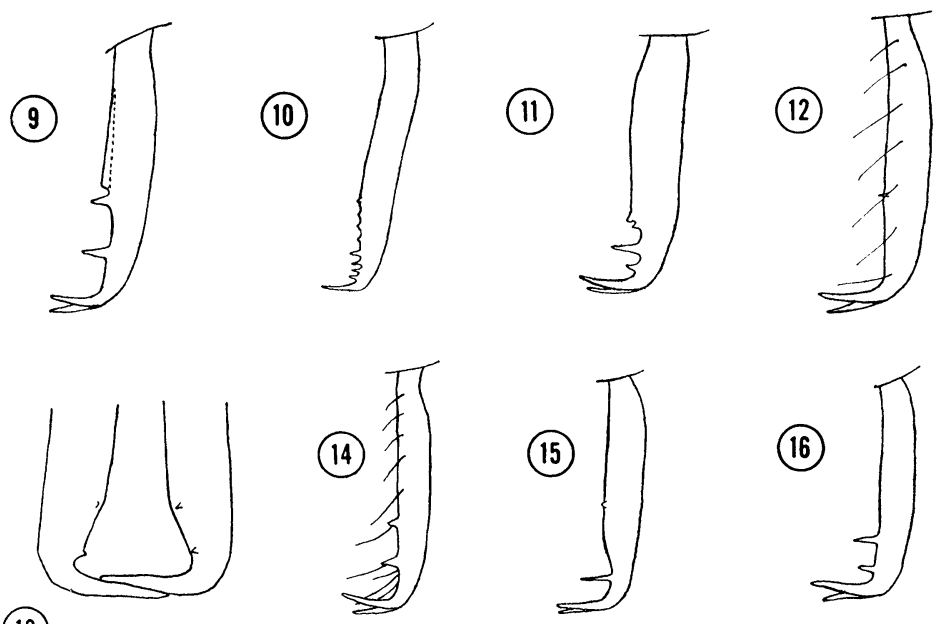

(13)
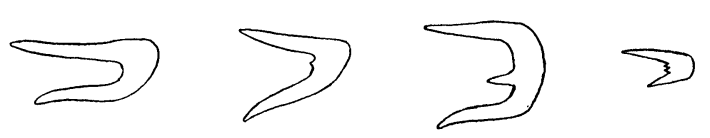

(17)

(18)

(19)

(20)

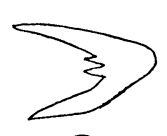

(21)

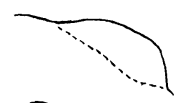

(22)

(23)

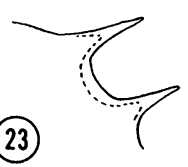

(24)

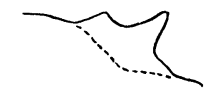

(25)<smiles>CC1CCC(C)C1</smiles>

(26)

(27)

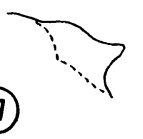

(28)<smiles>CC1CCC(C)C1</smiles>

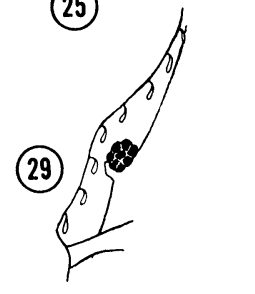


grandidieri Forel of Madagascar, precava of the present study (Fig. 7)], were primitive types within the genus, but now it seems to me that the opposite is true. S. loriae Emery (of the chyzeri group) and $S$. precava are viewed as derivative species with secondarily broadened prey specificity, and it is predicted that $S$. grandidieri will also eventually be found to feed on a wide range of small arthropods instead of the usual Strumigenys diet consisting mainly of collembolans. The powerful head and mandibles of these species are probably an adaptation to prey less fragile than Collembola.

Mandibular armament is probably the best character to use for determining direction of descent within Strumigenys. More primitive dacetine genera (Acanthognathus, Orectognathus, Microdaceton) have strumigenite mandibles with three long teeth in the apical fork; often the most dorsal of the three is also displaced slightly basad. In cases where such displacement has taken place, we have what in the genus Strumigenys would be called an apical fork (with two teeth) plus a preapical tooth. This is the condition found, with greater or lesser modification, in most Indo-Australian members of the genus as well as several New World species. In the African group, the species judged to be the more primitive ones have two preapical teeth, and derivative species mostly are smaller in size and tend to lose one or both distal preapical teeth. Quite a few of the New World forms, most notably those of the mandibularis group, have two well-developed preapical teeth on each mandible. In other New World forms, chiefly among smaller species, one or both of these teeth are present in greatly reduced form - in fact, in form so greatly reduced as to suggest that they serve no present function in holding struggling prey. It seems more likely to me that such feeble denticles represent vestiges of larger, functional teeth rather than the reverse, especially since so many of the species, and particularly the smaller species, have them. From this hint (which is no more than that), I take it that in the New World fauna of Strumigenys the mandibularis groups two large preapical teeth represent the primitive condition. The extensive radiation of undoubted mandibularis group species also speaks for a relatively long-term existence of this armament pattern. I have accordingly placed the mandibularis group at the base of my phyletic scheme (Fig. 30), despite the very good possibility that the earliest Strumigenys on a world basis may have had but a single preapical tooth.

The mandibularis group shows what appears to be a clear double morphocline. Beginning with a more "normal" or "average" species such as $S$. smithii, a string of species of increasing size and development (width) of occipital lobes, concurrent with a shortening and 
thickening of the mandibles, leads through $S$. planeti and S. godmani to $S$. mandibularis. In the other direction, we find a trend toward lengthening of the mandibles through the series $S$. biolleyi, S. saliens, $S$. sanctipauli and so on to the species near $S$. cordovensis, climaxed by the remarkable $S$. dolichognatha, the mandibles of which are relatively longer than in any other ant known to me. Side offshoots of the mandibularis group are species such as $S$. borgmeieri and $S$. trinidadensis; the greatly weakened proximal preapical tooth of the last species shows the first stages of a trend that apparently led to groups such as the hindenburgi and emeryi assemblages, and beyond these to the elongata and silvestrii groups respectively. Species such as $S$. perparva and $S$. ogloblini, both of which have a single preapical tooth on each mandible, were previously grouped together, but now I think it more likely that their similarities are due to convergence. Such highly reduced species are doubtfully placed at best.

The emeryi group, especially $S$. emeryi itself, is linked to the louisianae group by the virtually perfect intermediate $S$. mixta. The louisianae group leads to the connectens group and through this to the gundlachi group. These last three groups all have two (or rarely more) intercalary denticles between the main teeth of the apical fork. The genus Neostruma represents a further development of the louisianae group $\rightarrow$ connectens group $\rightarrow$ gundlachi group trend or morphocline.

The three remaining species groups, all small, appear to be derivable directly from the mandibularis group: the tococae group by addition of a second intercalary denticle in the apical fork, the cultriger group by development of a mandibular lamella, and the ludia group by the serial loss of mandibular teeth.

\section{Identification of Species}

This section is intended to provide materials with which any competent entomologist can hope to identify quickly and surely the Strumigenys species at present known from the New World. Of course, there are certainly species remaining to be discovered in this hemisphere, but I believe that we now know all or nearly all of the species that are both widespread and reasonably common, and many of the rare or local species as well.

Before discussing the species, though, it is necessary that we characterize the genus Strumigenys well enough to recognize it in this hemisphere. It will be enough to say that any New World ant with the following combination of characters is a Strumigenys: Worker and 
female - Exactly 6 antennal segments, of which the third and fourth are very short and the first (scape) and sixth (apical) are very long (Figs. I-4); mandibles long and linear, straight or bowed, more than $\mathrm{I} / 3$ as long as the head proper, with an apical fork of two prominent teeth, other teeth absent to few, usually separated (Figs. I-4, 7-16) ; occiput with a deep median posterior excision between two broad, rounded lobes, head in front distinctly narrowed (Figs. I-4); spongiform appendages, or at least their vestiges, present on petiole and postpetiole (Figs. 5, 6) ; head and often most of alitrunk reticulatepunctulate and opaque, rarely with superimposed rugulation. Males are not dealt with here, since few of them are known, and they cannot be separated as a group from a number of other dacetine genera.

Measurements, and the proportions derived from them, are very important in dacetine taxonomy, so it is necessary to measure with a high degree of accuracy. Measurements should be made to the nearest hundredth of a millimeter at least. A stereomicroscope magnifying at least $90 \times$ is required, plus a carefully calibrated reticule of the ocular squared disc type having finer subdivisions in one or more of the squares. The art of measuring dacetines is discussed at length elsewhere (Brown, 1953d: 7-I 5), so I shall repeat here just the essentials for use with this paper.

Head length (HL), maximum measureable length of head proper as seen from dorsal full-face view, including all of clypeus and occipital lobes.

Head width (HW) is the maximum width of the cranium measured in the same view as for HL.

Mandible length (ML), exposed length of mandibles, including apical teeth, measured in same view from which HL is obtained.

Weber's length (WL), oblique length of alitrunk from side view, measuring from base of anterior pronotal declivity to metasternal extremity.

Total length (TL) of the body is the summed lengths of ML, HL, WL plus the axial lengths of petiole, postpetiole and gaster measured separately.

Cephalic index $(\mathrm{CI})$, head width expressed as a percentage of head length, or $\mathrm{HW} / \mathrm{HL} \times$ ioo.

Mandibulo-cephalic index $(\mathrm{MI}), \mathrm{ML} / \mathrm{HL} \times$ Ioo.

In addition to the dichotomous key to the species, I have constructed a table giving known ranges of values for the seven quantitative characters most used in species-level taxonomy of the genus. This table may be used either as a primary key or as a check on the determinations made with the dichotomous key. Number of individuals 


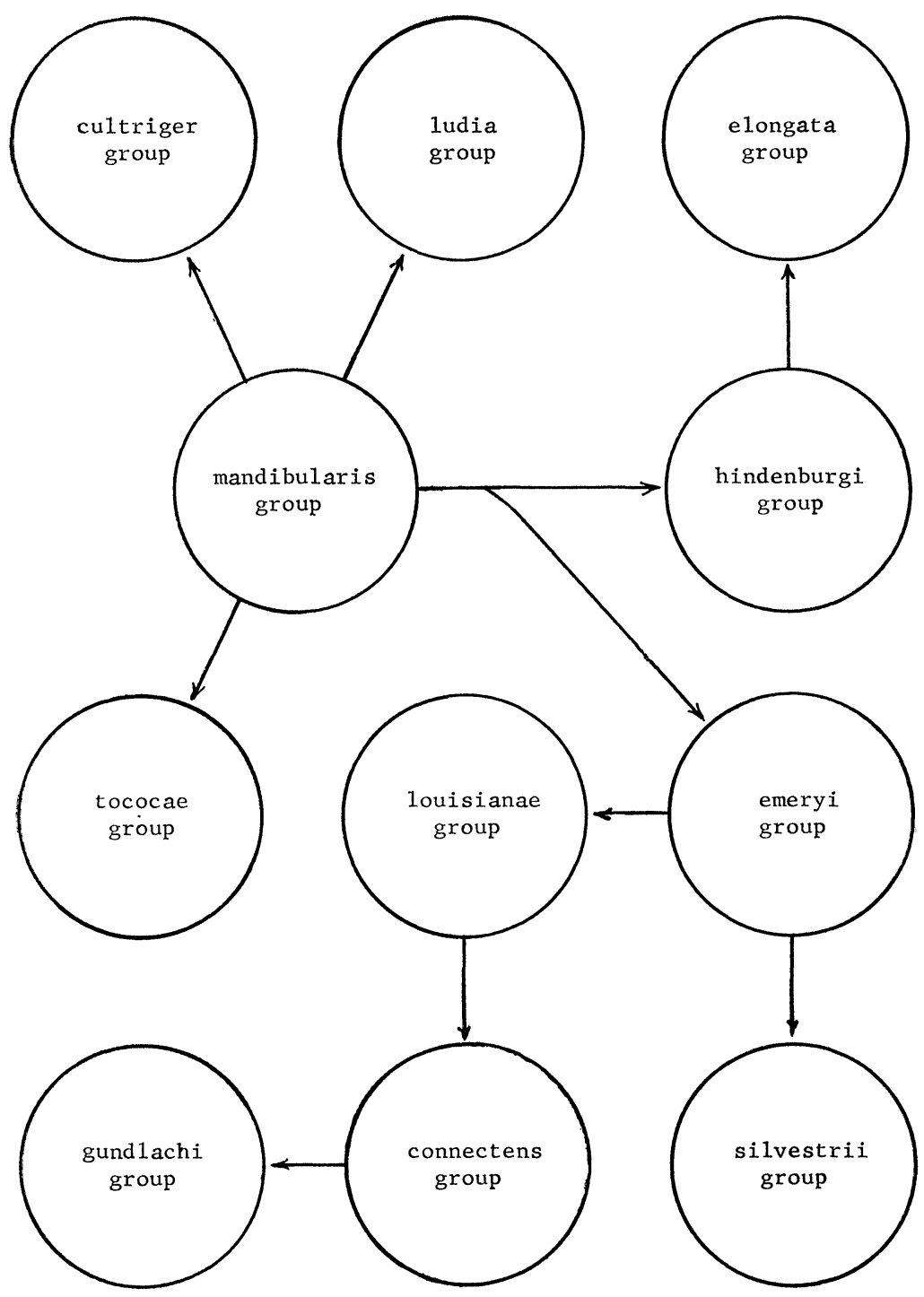

Figure 30. Diagram to illustrate the possible phyletic relationships among the species-groups of New World Strumigenys, based upon the hypothesis that the group of $S$. mandibularis represents the primitive stock in this hemisphere. $S$. rogeri, being African in origin, does not figure in this scheme. 
and localities on which the measurements were based are given under "Sample" so that the user can judge crudely how nearly the natural variance may be represented by the range of values given.

Following the dichotomous key is a glossary of the most important morphological terms used in species identification.

Table of the most valuable quantitative characters of the Strumigenys species of the New World

The table is arranged in order of size as based chiefly on head length. The measurements (in hundredths of millimeters) HL (head length), ML (mandibular length) and WL (Weber's diagonal length of alitrunk), as well as the proportions CI (cephalic index) and MI (mandibulo-cephalic index), are explained in the preceding section. ID indicates the number of small teeth or denticles lying between the two main teeth of the apical fork of the mandible, and PT is the number of teeth along the inner margin of the mandible proximad of the dorsal apical tooth (not counting the basal lamella, which is usually hidden beneath the clypeal margin); these preapical teeth may be large and spiniform or may be reduced to exceedingly minute denticles. The sample indicates the number of specimens measured and, following a dash, the number of separate localities represented by the specimens.

$\begin{array}{lcccccccc}\quad \text { Species } & \mathrm{HL} & \mathrm{CI} & \mathrm{ML} & \mathrm{MI} & \mathrm{WL} & \mathrm{ID} & \mathrm{PT} & \text { Sample } \\ \text { mandibularis } & 131 & \sim 102 & \sim 51 & \sim 38 & - & 1 & 2 & 1 \\ \text { godmani } & 106-120 & 87-93 & 51-55 & 46-48 & 109-122 & 1 & 2 & 8-2 \\ \text { sanctipauli } & 98 & 76 & 96 & 98 & 103 & 1 & 2 & 1 \\ \text { fairchildi } & 96 & 75 & 59 & 61 & 101 & 2 & 2 & 1 \\ \text { precava } & 87-101 & 71-79 & 50-56 & 54-61 & 81-97 & 1 & 1 & 92-7 \\ \text { sp. nr. micretes } & 86-90 & 75-76 & 58-61 & 67-68 & 92-99 & 1 & 0-2 & 25-1 \\ \text { saliens } & 81-95 & 69-77 & 50-60 & 60-65 & 82-97 & 1 & 1 & 38-9 \\ \text { dolichognatha } & 84-90 & 75-77 & 104-108 & 119-124 & - & 1 & 2 & 6-1 \\ \text { cultriger } & 85 & 77 & 51 & 60 & 90 & 1 & 2 & 1 \\ \text { planeti } & 80-89 & 80-86 & 45-50 & 52-57 & 80-90 & 1 & 2 & 39-5 \\ \text { tococae } & 80-85 & 75 & 44-47 & 55 & 80-87 & 2 & 2 & 8-1 \\ \text { trinidadensis } & 78-83 & 78-82 & 52-56 & 66-69 & 80-88 & 1 & 2 & 12-6 \\ \text { longispinosa } & 78-80 & 72-74 & 71-72 & 90-91 & 80-81 & 0 & 1 & 2-1 \\ \text { cordovensis } & 73-82 & 76-80 & 83-92 & 109-123 & - & 1 & 2 & 40-8 \\ \text { prospiciens } & 74-80 & 79-83 & 41-46 & 56-60 & 75-82 & 1 & 2 & 8-3 \\ \text { sublonga } & 74-79 & 76-80 & 72-75 & 96-98 & 73-79 & 1 & 2 & 7-1 \\ \text { rehi } & 76 & 76 & 76 & 100 & 80 & 1 & 2 & 1 \\ \text { borgmeieri } & 74 & 65 & 52 & 67 & 77 & 1 & 2 & 1 \\ \text { lacacoca } & 70-76 & 67-71 & 45-53 & 60-70 & 72-82 & 1 & 0-1 & 8-2\end{array}$




$\begin{array}{lcccccccc}\text { micretes } & 70-76 & 71-74 & 45-51 & 62-68 & 72- & 1 & 2 & 18-2 \\ \text { smithii } & 67-76 & 80-87 & 36-42 & 52-61 & 70-78 & 1 & 2 & 26-6 \\ \text { biolleyi } & 60-81 & 78-85 & 35-51 & 58-66 & -86 & 1 & 2 & 51-11 \\ \text { ludia } & 67-74 & 81-84 & 49-56 & 73-76 & 62-73 & 1 & 0 & 9-6 \\ \text { marginiventris } & 68-73 & 78-82 & 51-57 & 75-79 & 68-72 & 0 & 1 & 11-3 \\ \text { producta } & 65-70 & 78-82 & 45-48 & 69-70 & 69-74 & 2 & 1 & 15-1 \\ \text { consanii } & 64-66 & 78-80 & 41-42 & 63-64 & 76-80 & 0 & 0 & 5-1 \\ \text { hindenburgi } & 60-69 & 83-88 & 38-40 & 58-64 & 63-71 & 1 & 2 & 9-3 \\ \text { deltisquama } & 62-67 & 95-97 & 34 & 51-55 & 60-63 & 1 & 2 & 12-1 \\ \text { xenognatha } & 65 & 79 & 41 & 63 & 84 & 2 & 2 & 1 \\ \text { connectens } & 60-65 & 81-86 & 33-37 & 53-56 & 64-73 & 2 & 3-4 & 7-2 \\ \text { nevermanni } & 61-63 & 77-80 & 36-38 & 58-60 & 67- & 1 & 1 & 8-1 \\ \text { emeryi } & 59-64 & 80-82 & 38-40 & 61-64 & 65-69 & 1 & 2 & 10-4 \\ \text { laevipleura } & 58-62 & 79-82 & 33-35 & 56-57 & 65-66 & 2 & 3 & 3-1 \\ \text { hemidisca } & 60 & 82 & 39 & 65 & 64 & 1 & 2 & 3-1 \\ \text { rogeri } & 57-62 & 70-74 & 30-34 & 53-55 & - & 0 & 2 & 11-9 \\ \text { trieces } & 58 & 78 & 28 & 48 & 62 & 2+? & 3 & 1 \\ \text { elongata } & 50-63 & 72-79 & 28-41 & 56-67 & 47-62 & 0 & 0 & 161-25 \\ \text { ogloblini } & 55-56 & 80-81 & 28-29 & 51-52 & \sim 55 & 1 & 1 & 2-1 \\ \text { louisianae } & 46-64 & 77-92 & 23-37 & 49-67 & - & 2 & 1 & 130-71 \\ \text { mixta } & 51-59 & 80-84 & 28-32 & 54-60 & 51-60 & 2 & 2 & 20-2 \\ \text { jamaicensis } & 52-56 & 81-82 & 40-42 & 75-77 & 55-57 & 2 & 6-8 & 12-2 \\ \text { boneti } & 50-56 & 80-82 & 28-30 & 50-60 & 50-57 & 1 & 1 & 4-3 \\ \text { subedentata } & 48-56 & 82-86 & 26-30 & 53-54 & 47-60 & 2 & 4-6 & 36-15 \\ \text { denticulata } & 42-48 & 77-80 & 31-39 & 74-83 & 42-49 & 2 & 5-9 & 11-6 \\ \text { gundlachi } & 40-49 & 79-86 & 24-32 & 59-66 & 40-50 & 2 & 4-9 & 36-20 \\ \text { silvestrii } & 42-47 & 77-81 & 24-26 & 55-60 & 41-50 & 1 & 2 & 11-4 \\ \text { eggersi } & 39-47 & 83-88 & 22-27 & 56-64 & 39-46 & 2 & 4-8 & 32-22 \\ \text { schmalzi } & 42 & 79 & 27 & 64 & 44 & 0 & 2 & 1 \\ \text { perparva } & 40 & 81 & 20 & 50 & 40 & 0 & 1 & 2-1 \\ \text { carinithorax } & 36 & 81-83 & 21-22 & 59-61 & 41 & 0 & 2 & 3-1\end{array}$

Dichotomous key to the known species of Strumigenys occurring in the New World, based chiefly on the worker caste, but applying to the females of most species as well

I. Apical fork of mandible without distinct intercalary teeth or denticles (Fig. I7) 2. Apical fork of mandible with a single intercalary tooth or denticle, either separate or occurring as a spur on the inner side of the ventral tooth (Figs. I8, I9) 9. Apical fork of mandible with 2 (rarely 3-4) intercalary denticles (Figs. 20, 2I) 38.

2. Mandible without preapical teeth or denticles (Fig. I) ............. 3 . Mandible with I or 2 preapical teeth and/or denticles (Fig. I6) 
3. Postpetiole large and convex, its dorsum smooth and shining; larger, more robust species (Costa Rica) consanii Brown Postpetiole small, its dorsum densely punctulate and opaque; smaller, more slender species (s. Mexico to se. Brazil and Bolivia) elongata Roger

4. First segment of gaster margined for its full length on each side by a strong, raised dorsolateral carina (Costa Rica to Colombia) marginiventris Santschi

First gastric segment smoothly rounded dorsolaterally, without raised margins apart from the basal costulae

5. Larger species with very long mandibles; combined length of head + mandibles $>$ I. IO mm (Panama) ... longispinosa Brown Smaller species with mandibles not so long; combined length of head + mandibles $<$ I. Io $\mathrm{mm}$

6. Compound eye anteriorly detached, i.e., bounded in front by a narrow cleft or notch in the ventrolateral margin of the head (Fig. 29) ; combined length of head + mandibles $>0.80 \mathrm{~mm}$; 2 preapical teeth on each mandible, the distal being smallest (Figs. I6, I7) (West Indies, Trinidad, British Guiana, introduced from Africa) rogeri Emery No preocular notch in ventrolateral border of head; combined length of head + mandibles $<0.80 \mathrm{~mm}$

7. Each mandible with a single preapical tooth; no minute denticle near mandibular midlength (Trinidad to se. Brazil)

perparva Brown In addition to the preapical tooth, each mandible bears a minute denticle somewhere near the midlength of its inner margin ..... 8 .

8. Mandibles ( MI 54-6I ), scape ( $\mathrm{L} 0.23 \mathrm{~mm}$ ) and apical funicular segment ( $\mathrm{L}$ ca. $0.22 \mathrm{~mm}$ ) shorter; promesonotum with a distinct median longitudinal carina (Dutch Guiana)

carinithorax Borgmeier Mandibles $(\mathrm{MI}>6 \mathrm{I})$, scape $(\mathrm{L}>0.27 \mathrm{~mm})$ and apical funicular segment: $(L>0.25 \mathrm{~mm}$ ) longer; no distinct carina in the middle of the promesonotum (se. Brazil) ......... schmalzi Emery

9. Mandible with no preapical teeth, or with a single preapical tooth or denticle, or with a preapical tooth or denticle plus another minute denticle proximal to it (Figs. I-4, 7, 8, I2, I3) ...... Io. Mandible with 2 well-developed preapical teeth (Figs. 9, I4)... ro. Mandible without preapical teeth or denticles (Fig. 2) ....... I I. Mandible with a preapical tooth or denticle, or both (Figs. 3, 4, 7, 8, 12, I 3, 15) ................................................. I 2. 22.

I I. Petiole claviform, the node only feebly differentiated from its 
anterior peduncle; gastric hairs mostly stiff, remiform (i.e., with broadened apices) (Fig. 5); head broader (CI $>$ 79; Fig. I) (Nicaragua to s. Mexico) .................................. ludia Mann Petiolar node with a steep anterior face, set off from its anterior peduncle; gastric hairs long, finely flagelliform (Fig. 6) ; head narrower ( $\mathrm{CI}<78$; Fig. 2 ) lacacoca; go to $2 \mathrm{I}$

12. Large hairs of gastric dorsum remiform (i.e., oar- or paddleshaped at apex) ; smaller species I3. Large hairs of gastric dorsum fine, long, flagelliform .......... I 5 .

I3. First gastirc tergite reticulate-punctulate and opaque; preapical armament of mandible reduced to a single minute denticle situated somewhat distal to the midlength of the inner border, but remote from the apex (Fig. I2) (s. Mexico) ....... boneti Brown First gastric tergite smooth and shining beyond the basal belt of longitudinal costulae; preapical armament of mandible consisting of a distinct tooth, with or without an additional minute denticle near mandibular midlength

I 4. Dorsal borders of antennal scrobes broad, lamellose; preapical armament of mandible consisting of a single strong tooth ( $\mathrm{n}$. Argentina) ogloblini Santschi Dorsal scrobe borders merely narrowly cariniform; preapical mandibular armament consisting of a tooth near the apex plus an additional minute denticle near the midlength ( $\mathrm{n}$. Argentina to s. Brazil; also Cuba and Louisiana, where probably introduced) silvestrii Emery

I5. Ventral ends of propodeal lamellae at most rounded or bluntly angulate, not dentiform I6. Propodeal teeth large and acute, matched on each side below by a (metasternal) tooth of nearly the same size and shape arising from the ventral end of the infradental lamella (Fig. 23)

trinidadensis; go to 26.

16. Long fine flagelliform hairs on nodes of petiole and postpetiole and on gastric dorsum very numerous, too many to count, and evidently always $>\mathrm{I} 6+2 \mathrm{O}+5 \mathrm{O}$, or $>86$ total (partially denuded specimens or those with hairs plastered down can of course be deceptive)

Long flagelliform hairs of nodes and gastric dorsum much fewer, at most about $8+$ IO +34 , or about 52 hairs total I 8 .

I7. Dorsal scrobe border on each side produced as a narrow but distinctly lamellar margin; inner mandibular border with a minute denticle near the apical third, in addition to the preapical tooth; basal gastric costulae short, coarse, remainder of first 
tergite smooth and shining (Fig. 8; Argentina, se. Brazil)

hindenburgi Forel

Dorsal scrobe borders merely narrowly cariniform, not lamellate; mandibles without preapical dentical proximad of preapical tooth; basal costulae of gastric dorsum extended over basal third or more of first tergite as fine, sericeous-opaque striolation (Fig. 4; C. America to s. Mexico; Bahamas) ........... lanuginosa Wheeler

I8. Head with a strong concavity anterior to each eye, and thus appearing constricted in full-face view (Fig. 7) ; humeral tubercles large and produced (mandibles broad, contiguous or nearly so when closed, each with a single short, broad preapical tooth; Fig. 7) (Panama; hylaean S. America to Bolivia)

precava Brown

Head parallel-sided or gently tapered in front of eyes, without marked preocular concavities; humeral tubercles or angles small, not produced (mandibles slender, not contiguous at full closure, preapical dentition diverse, but not as above) I9.

I9. Smaller species, with mandibles $<0.42 \mathrm{~mm}$ long; head broader $(\mathrm{CI}>75)$ 20. Larger species, with longer mandibles $(\mathrm{ML}>0.42 \mathrm{~mm})$; head narrow (CI 75 or less) $2 \mathrm{I}$.

20. Inner mandibular margin with a minute denticle near the apical third in addition to the preapical tooth; head distinctly longitudinally rugulose (s. Mexico, Honduras) ............... emeryi Mann Mandible with a single preapical tooth and no additional denticles proximad of this (Fig. 3); head at most weakly and indistinctly rugulose above (Costa Rica) ...................... nevermanni Brown

2I. Mandible with a small preapical tooth or denticle and, near it proximally, an additional minute denticle (Fig. I3; Costa Rica, Panama) micretes Brown Mandible with no teeth or denticles, or with a single minute preapical denticle (Fig. 2 ; Panama) lacacoca Brown (A population from Boquete, Chiriqui Prov., Panama, has I or 2 preapical denticles on the inner mandibular border, and is thus intermediate between micretes and lacacoca, but this population is also distinctive in having the promesonotum coarsely longitudinally striate. The specimens are also larger. Possibly micretes, lacacoca and the Boquete sample are simply local variants of a single unusually variable species, or perhaps three distinct species are represented here.)

22. Inner mandibular border extended as a straight-edged lamella that terminates abruptly and subangularly at its distal end near 
the proximal preapical tooth (Fig. 9) 23. Inner mandibular border without a lamellar extension, or, if a lamella of sorts is present, its form is not as above (Fig. I4) .. 24.

23. Lamelliform margin of inner mandibular border ending near midlength of mandible ( $\mathrm{Fig} .9$ ) ; propodeal teeth very small; gastric dorsum predominantly smooth and shining, with vestiture of abundant fine, short reclinate hairs (se. Brazil) .. cultriger Mayr Lamelliform margin of inner mandibular border ending near apical quarter of mandible; propodeal teeth large; first gastric tergite predominantly reticulate-striate, opaque, with about 20 apically-broadened, short erect hairs (Panama)

deltisquama Brown

24. Large forms (head width $>0.85 \mathrm{~mm}$ ) with massive head and short, heavy mandibles (MI 50 or less) 25. Smaller forms with narrower heads (head width under $0.85 \mathrm{~mm}$ ) and longer, more slender mandibles $(\mathrm{MI}>5 \mathrm{O})$ 26.

25. First gastric tergite finely longitudinally striolate for most or all of its length; head about as broad as, or broader than, long (Amazon Basin) mandibularis Fr. Smith Gastric dorsum smooth and shining, with only a narrow basal band of reduced costulae; head slightly longer than broad (Guiana to Costa Rica) godmani Forel

26. Gastric dorsum predominantly finely longitudinally striolate, sericeous-opaque, with very abundant, fine, erect flagelliform pilosity; proximal preapical mandibular tooth small (only about half the length of the distal preapical) and situated toward the mandibular midlength (Fig. I4; Trinidad to Bolivia and Ecuador) trinidadensis Wheeler Gastric dorsum with either sculpture or pilosity or both different from the above; proximal preapical tooth of mandible more than half as long as distal preapical tooth and situated well beyond the mandibular midlength

27. Mandibles very nearly as long as, to distinctly longer than, the head proper $(\mathrm{MI}>90)$ 28. Mandibles relatively shorter $(\mathrm{MI}<75)$ 32.

28. Mandibles slightly $>$ I.OO $\mathrm{mm}$ long; distal preapical tooth closer to proximal than to apical fork (British Guiana)

dolichognatha Weber

Mandibles < $1.00 \mathrm{~mm}$ long; distal preapical tooth closer to apical fork than to proximal preapical tooth

29. Mandibles $>0.80 \mathrm{~mm}$ long; longitudinal costulation of postpetiolar disc absent or incomplete 
Mandibles $<0.80 \mathrm{~mm}$ long; longitudinal costulation on postpetiolar disc complete from anterior to posterior border

3o. Size larger (HL $0.98 \mathrm{~mm}$ in holotype worker); infradental lamella of propodeum low and cariniform, terminating below in a small, obtuse ventral angle that is much smaller than the dorsal tooth (Fig. 24); antennal scape straight to its base (se. Brazil) sanctipauli Kempf

Size smaller $(\mathrm{HL}<0.85 \mathrm{~mm})$; infradental lamella high, terminating below in a prominent tooth or angle which is subequal to, or often larger than, the dorsal propodeal tooth (Figs. 25-27) ; antennal scapes gently but distinctly curved in basal half ( $\mathrm{s}$. Mexico to Trinidad and the Guianas) cordovensis Mayr

3I. Pilosity of head, alitrunk and nodes rather abundant and conspicuous, narrow-spatulate; eyes $0.09 \mathrm{~mm}$ in greatest diameter; MI roo \pm (Amazon Basin) rehi Forel Pilosity less abundant and conspicuous, that of nodes and first gastric segment sparse, fine and filiform; eyes $0.07-0.08 \mathrm{~mm}$ in greatest diameter; MI 94-99 (Amazon Basin) .. sublonga Brown

32. Propodeal lamellae evenly rounded, without dorsal or ventral angles or teeth (Fig. 22 ; Colombia) hemidisca Brown Propodeal lamellae angulate or toothed above and/or below, more or less as in Figs. 23, 24 or 28

33. Propodeal lamellae without dorsal teeth or angles; ventral angle present and prominent (Fig. 28 ; C. America s. to Ecuador)

biolleyi Forel

Propodeal lamellae angulate or toothed both above and below (more or less as in Figs. 23-26)

34. Mandibles longer and more slender $(M I>63)$; head narrower $(\mathrm{CI}<8 \mathrm{o})$

Mandibles shorter and more robust $(M I<63)$; head broader (CI 80 or more)

35. Smaller $(\mathrm{HL}<0.80 \mathrm{~mm})$, more slender $(\mathrm{CI}<68)$; preapical teeth small and crowded toward apical fork, occupying little or no more than the apical I/5 of the mandibular length (Brazil: Pernambuco) borgmeieri Brown Larger ( $\mathrm{HL}$ o.80 $\mathrm{mm}$ or more), not so slender ( $\mathrm{CI}>68$ ); preapical teeth more widely spaced, occupying the apical $2 / 5$, more or less, of the mandibular length (se. Brazil, n. Argentina) saliens Mayr

36. Larger ( $\mathrm{HL}$ o.80 $\mathrm{mm}$ or more), with heavy, distinctly arcuate mandibles planeti Brown 
Smaller $(\mathrm{HL}<0.80 \mathrm{~mm})$; mandibles narrower, not or only indistinctly arcuate

37. Basigastric costulae absent or extremely reduced, never much longer than the space separating one from the next; anterodorsal face of petiolar node convex in both directions (Amazon Basin to Bolivia) prospiciens Emery Basigastric costulae fine but numerous, extending at least $\mathrm{I} / 8$ the length of gastric tergite I; anterodorsal face of petiolar node obliquely depressed, nearly or quite plane (tropical S. and C. America, St. Vincent I.) smithii Forel

38. Mandible with a single small preapical tooth; no additional preapical teeth or denticles on inner border 39. Mandible with 2 or more preapical teeth and/or denticles .... 40.

39. Larger form with long mandibles ( $\mathrm{ML}>0.42 \mathrm{~mm}$; MI 68 or more; see discussion, p. 247) (Bolivia) ........... producta Brown Smaller form with shorter mandibles $(M L<0.42 \mathrm{~mm}$; MI $<$ 68) (Tennessee and Arizona to n. Argentina and Bolivia, W. Indies) louisianae Roger

40. Mandible with at most 2 preapical teeth and/or denticles (Fig. I5) Mandible with 3 or more preapical teeth and/or denticles (Figs. IO, II ) 44 .

4I. Mandible with I preapical tooth and a single additional minute denticle near the apical third of the mandibular length (Fig. I5) ; gastric dorsum predominantly reticulate-striate, opaque, with stiff remiform erect hairs (Guatemala) mixta Brown Mandible with two well-developed preapical teeth 42.

42. Smaller species, $\mathrm{HL}<0.75 \mathrm{~mm}$; erect hairs of gaster stiff, slightly clavate or remiform (known from female only; possibly an inquiline in nest of $S$. laevipleura; Colombia)

xenognatha Kempf

Larger forms, HL > $0.75 \mathrm{~mm}$; erect hairs of gaster few, straggling flagelliform

43. Dorsum of basal gastric segment with longitudinal costulae only at base, otherwise smooth and shining; short, thickened reclinate ground hairs of gastric dorsum abundant and conspicuous (Amazon Basin) tococae Wheeler Dorsum of basal gastric segment longitudinally striolate for its full length; reclinate ground hairs of gastric dorsum obsolete or apparently so (Panama) fairchildi Brown

44. Postpetiolar node smooth and shining when clean; mandible with 2 preapical teeth and a denticle (Colombia) .... laevipleura Kempf 
Postpetiolar node densely reticulate-punctulate, opaque 45.

45. Preapical armament of mandible consists of 2 close-set preapical teeth, of which the second is much the longer, followed closely basad by I or 2 denticles (Fig. I I) (Colombia)

connectens Kempf

Preapical armament otherwise; consisting either of three small subequal teeth, or of 4-9 minute teeth and/or denticles (Fig. Io)

46. Antennal scape $0.33 \mathrm{~mm}$ or more long; larger, dark-colored species (Jamaica) jamaicensis Brown Antennal scape $<0.33 \mathrm{~mm}$ long

47. Mandibles short and thick $(\mathrm{MI}<56$ ) ; robust species, worker $\mathrm{HL}$ mostly $>0.48 \mathrm{~mm}$ 48. Mandibles longer and slender (MI 56 or more) ; smaller species, worker HL mostly 0.48 or less (Fig. IO)

48. Mandible short (MI 48 in unique holotype), with exactly 3 small preapical teeth; ground pilosity of head nearly or quite obsolete; pronotum markedly flattened (Costa Rica)

trieces Brown

Mandible relatively longer ( MI ca. 53-54), with $>3$ preapical teeth and/or denticles; ground pilosity abundant and conspicuous on head; promesonotum strongly rounded, not depressed (Mexico to s. Brazil) subedentata Mayr

49. Mandibles very long and slender $($ MI $>70)$, bowed outward (Trinidad to n. Argentina) denticulata Mayr Mandibles not so long $(\mathrm{MI}<7 \mathrm{O})$, their shafts approximately straight (Fig. IO)

50. Ventral spongiform appendages of postpetiole small but distinctly developed (side view) ; gastric dorsum of worker predominantly smooth and shining (when clean!), at most with a few basal. longitudinal costulae, but female gaster commonly shagreened above (Caribbean countries) gundlachi (Roger) Ventral spongiform appendages of postpetiole obsolete; gastric dorsum of both worker and female with fine, mostly opaque reticulation (Brazil, Bolivia, Caribbean countries)

eggersi Emery

\section{Glossary}

Alitrunk: The second tagma of the body in Hymenoptera, incorporating the thorax and the closely fused propodeum (first true abdominal segment). 
Antennal scrobes: Broad longitudinal excavations or grooves, one on each side of the head above the eye, for the reception of the folded antennae.

Apical fork: The two large teeth at the extreme apex of the mandible, converging to form a $\mathrm{U}$ or $\mathrm{V}$; between them may occur one or more intercalary denticles (Figs. 9-2 I ).

Basal costulae (basigastric costulae): Numerous raised longitudinal lines of the integumental sculpture originating from the base of the first gastric segment (tergite) and extending caudad for distances varying with the species (Figs. 5, 6).

Basal tooth (or lamella): A process, usually digitiform or dentiform, arising from the inner mandibular border at its base, and usually covered by the clypeus when the mandibles are closed; not to be confused with the preapical teeth.

Flagelliform hairs: Very long, slender, tapered setae, often wavy, looped or otherwise contorted, i.e., whip-like (Figs. 4, 6).

Intercalary tooth (or denticle): Abbreviated "ID," a tooth (or denticle) occurring between the main teeth of the apical fork of the mandible, or as a spur on the inner side of one of the main teeth (Figs. I 8-2I).

Preapical tooth (or denticle): Abbreviated "PT," a tooth (or denticle), one or more of which occur along the inner mandibular border proximal to the apical fork, but not at or beneath the clypeal margin; not to be confused with the basal tooth, q. v. (Figs. 3, 4, 7-I6).

Propodeal lamella: One of a pair of raised lobes or flanges guarding the sides of the propodeal declivity, sometimes incorporating the (dorsal) propodeal tooth and/or a ventral (metasternal or metapleural) tooth or angle (Figs. 5, 6, 22-28).

Remiform hairs: Setae with a more or less oar-like form (Fig. 5).

Spongiform appendages: Lobes, flaps and collar-like strips of lightcolored spongy integumental material situated in definite, symmetrical positions on the petiole, postpetiole and anteroventral face of the gaster (Figs. 5, 6), and sometimes even on the alitrunk, in the higher dacetines and a few other ants. Their function is unknown. 


\section{INDEX TO NAMES OF STRUMIGENYS SPECIES OF THE NEW WORLD AND THEIR SYNONYMS}

(Names in italics are synonyms; page references are to the accompanying article)

\author{
angusticeps = saliens, 240 , \\ banillensis = gundlachi, 249 \\ batesi $=$ mandibularis, 239 \\ berlese $i=$ gundlachi, 249 \\ bierigi $=$ gundlachi, 249 \\ biolleyi, 240, 253, 257, 262 \\ boneti, 245, 257, 259 \\ borgmeieri, 240, 253, 257, 262 \\ bruchi $=$ louisianae, 247 \\ caribbea $=$ silvestrii, 246 \\ carinithorax, 246, 257, 258 \\ clasmospongia = louisianae, 247 \\ clavata $=$ subedentata, 248 \\ connectens, 247, 253, 257, 264 \\ consanii, $245,257,258$ \\ cordovensis, 241, 253, 256, 262 \\ costaricensis $=$ louisianae, 247 \\ cubaensis = louisianae, 247 \\ cultriger, 241, 253, 256, 261 \\ deltisquama, 241, 257, 261 \\ denticulata, 249, 257, 264 \\ dolichognatha, 241, 253,256, 261 \\ eggersi, 249, 257, 264 \\ elongata, 245, 253, 257, 258 \\ emeryi, 245, 253, 257, 260 \\ fairchildi, 241, 242, 256, 263 \\ ferox $=$ godmani, 239 \\ fusca $=$ louisianae, 247 \\ godmani, 239, 253, 256, 261 \\ guatemalensis = louisianae, 247 \\ gundlachi, 249, 253, 257, 264 \\ hemidisca, 239, 257, 262 \\ hindenburgi, 243, 253, 257, 260 \\ imitator = elongata, 245 \\ inaequalis = smithii, 239 \\ incisa $=$ rogeri, 250 \\ infidelis = louisianae, 247 \\ infuscata = gundlachi, 249 \\ isthmica = gundlachi, 249 \\ jamaicensis, 249, 257, 264 \\ lacacoca, 245, 256, 259, 260 \\ laevipleura, 247, 248, 257, 263 \\ lanuginosa, 243, 260
}

laticephala $=$ louisianae, 247

longicornis = louisianae, 247

longispinosa, 242, 256, 258

louisianae, 246, 247, 253, 257, 263

luctuosa $=$ biolleyi, 240

ludia, 242, 243, 253, 257, 259

mandibularis, 238, 252, 256, 261

marginiventris, 242, 257, 258

micretes, 245, 256, 257, 260

mixta, 246, 253, 257, 263

mokensis, 241

nevermanni, 245, 257, 260

nicaraguensis $=$ elongata, 245

obscuriventris = louisianae, 247

ogloblini, 243, 253, 257, 259

perparva, 246, 253,257, 258

planeti, 239, 253, 256, 262

precava, 243, 245,252, 256, 260

procera $=$ saliens, 240

producta, 247, 257, 263

prospiciens, 238, 239, 256, 263

rehi, 240, 241, 256, 262

rogeri, 249, 250, 257, 258

saliens, 240, 253, 256, 262

sanctipauli, 240,253,256, 262

schmalzi, 246, 257, 258

silvestrii, 246, 253, 257, 259

smithii, 239, 252, 257, 263

soledadensis = louisianae 247

subedentata, 248, 257, 264

sublonga, 240, 256, 262

sulfurea $=$ rogeri, 250

tenuis = ludia, 243

tococa e, 241, 253,256, 263

tridens $=$ biolleyi, 240

trieces, 248, 257, 264

trinidadensis, 240,253,256, 259, 261

tristani $=$ subedentata 248

unidentata $=$ louisianae 247

unispinulosa = louisianae 247

vincentensis $=$ gundlachi 249

xenognatha, 248, 257, 263 


\section{REFERENCES}

Brown, W. L., JR.

1948. A preliminary generic revision of the higher Dacetini (Hymenoptera: Formicidae). Trans. Amer. Ent. Soc., 74: 101-129.

1953a. Three new ants related to Strumigenys louisianae. Psyche, 60:1-5.

1953b. The neotropical species of the ant genus Strumigenys Fr. Smith: Group of mandibularis Fr. Smith. Jour. N. Y. Ent. Soc., 61 : 53-59.

1953c. The neotropical species of the ant genus Strumigenys Fr. Smith: Group of smithii Forel. Jour. N. Y. Ent. Soc., 61:101-110.

1953d. Revisionary studies in the ant tribe Dacetini. Amer. Midl. Nat.. $50: 1-137$, ill.

1954a. The neotropical species of the ant genus Strumigenys Fr. Smith: Group of elongata Roger. Jour. N. Y. Ent. Soc., 61 : 189-200, 1953.

1954b. The neotropical species of the ant genus Strumigenys Fr. Smith: Group of saliens Mayr. Jour. N. Y. Ent. Soc., 62: 55-62.

1957. The neotropical species of the ant genus Strumigenys Fr. Smith: Group of cultriger Mayr and S. tococae Wheeler. Jour. N. Y. Ent. Soc., 63 : 97-102, 1955.

1958a. The neotropical species of the ant genus Strumigenys Fr. Smith: Group of cordovensis Mayr. Stud. Ent., Petropolis, Brazil, (n.s.) 1: 217-224.

1958b. The neotropical species of the ant genus Strumigenys Fr. Smith: Group of marginiventris Santschi. Jour. N. Y. Ent. Soc., 65: 123$128,1957$.

1958c. The neotropical species of the ant genus Strumigenys Fr. Smith: Group of ogloblini Santschi. Jour. N. Y. Ent. Soc., 65: 133-137, 1957.

1959a. The neotropical species of the ant genus Strumigenys Fr. Smith: Group of emeryi Mann. Ent. News, 70: 97-104.

1959b. Some new species of dacetine ants. Brev. Mus. Comp. Zool., 108: $1-11$.

1959c. The neotropical species of the ant genus Strumigenys Fr. Smith: Group of silvestrii Emery. Stud. Ent., Petropolis, Brazil, (n.s.) 2: 25-30.

1960. The neotropical species of the ant genus Strumigenys Fr. Smith: Group of gundlachi (Roger). Psyche 66:37-52, 1959.

1961. The neotropical species of the ant genus Strumigenys Fr. Smith: Miscellaneous concluding studies. Psyche, 68: 58-69.

KeMPF, W. W.

1958a. Three new ants of the genus Strumigenys from Colombia. Rev. Brasil. Ent., 8 : 59-68.

1958b. The ants of the tribe Dacetini in the State of São Paulo, Brazil, with the description of a new species of Strumigenys (Hymenoptera: Formicidae). Stud. Ent., Petropolis, Brazil, (n. s.) 1:553-560.

Weber, N. A.

1952. Biological notes on Dacetini (Hymenoptera, Formicidae). Amer. Mus. Novit., 1554 : 1-7.

WILson, E. O.

1950. Notes on the food habits of Strumigenys louisianae Roger (Hymenoptera: Formicidae). Bull. Brooklyn Ent. Soc., 45 : 85-86.

1954. The ecology of some North American dacetine ants. Ann. Ent. Soc. Amer., 46: 479-495, 1953. 

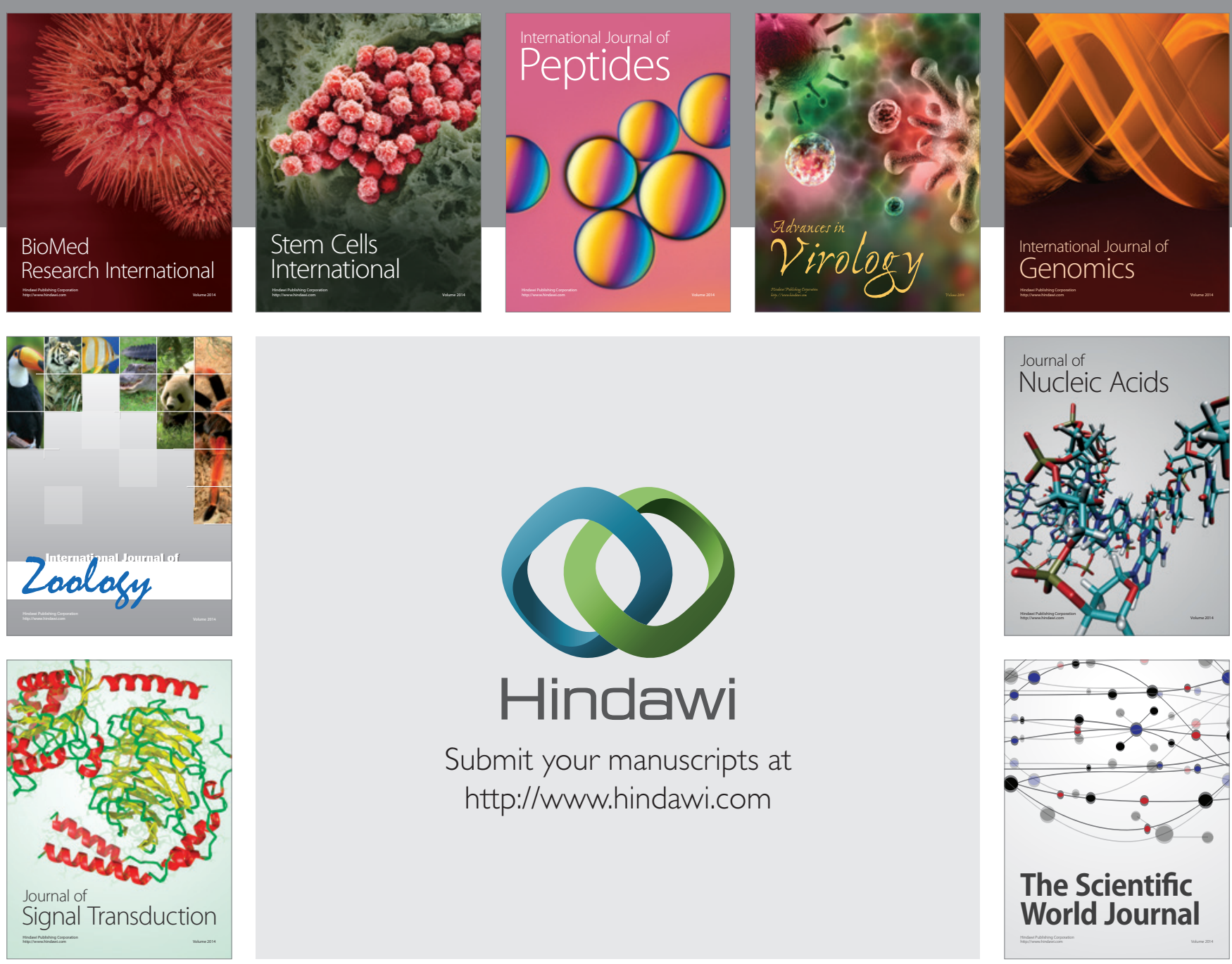

Submit your manuscripts at

http://www.hindawi.com
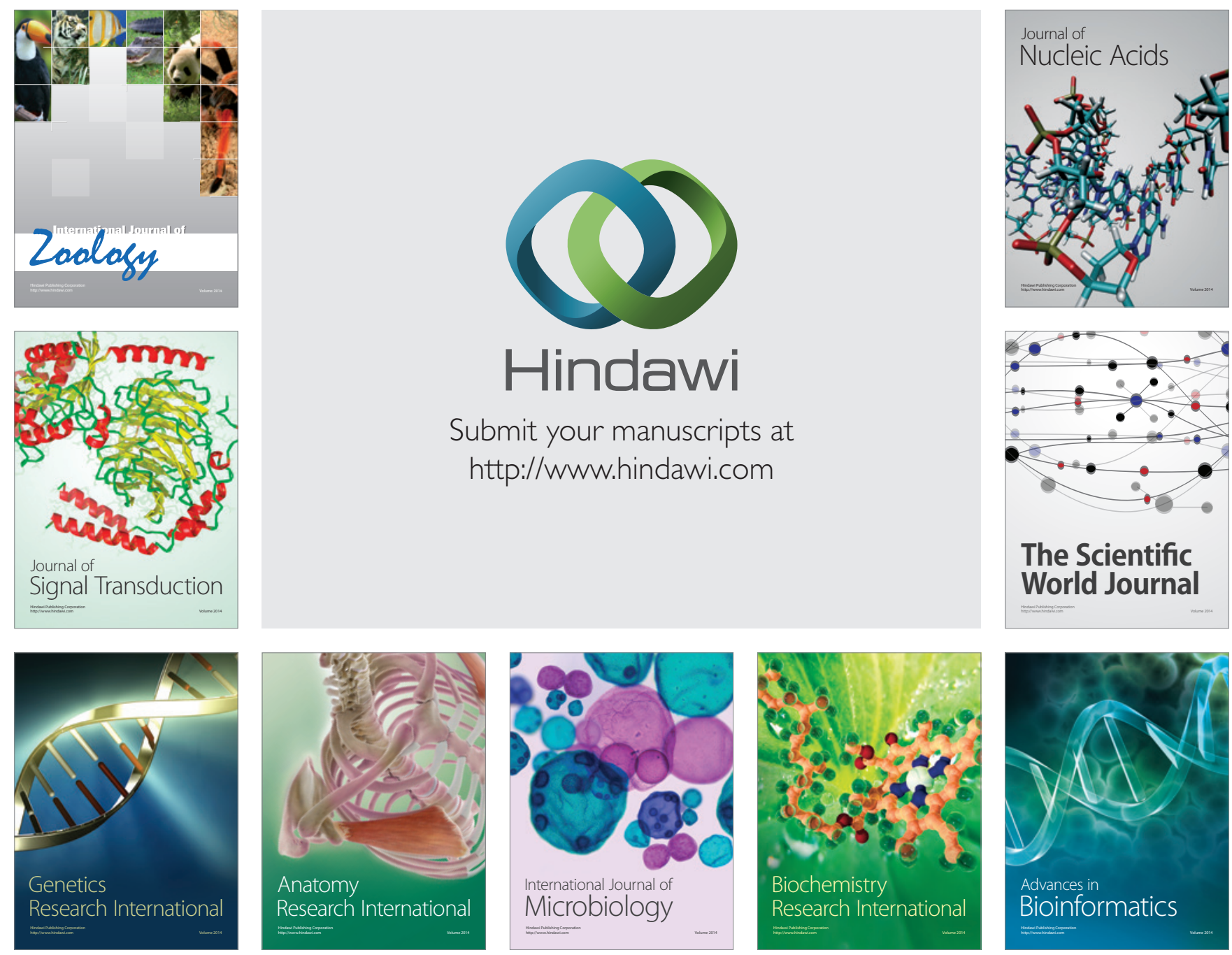

The Scientific World Journal
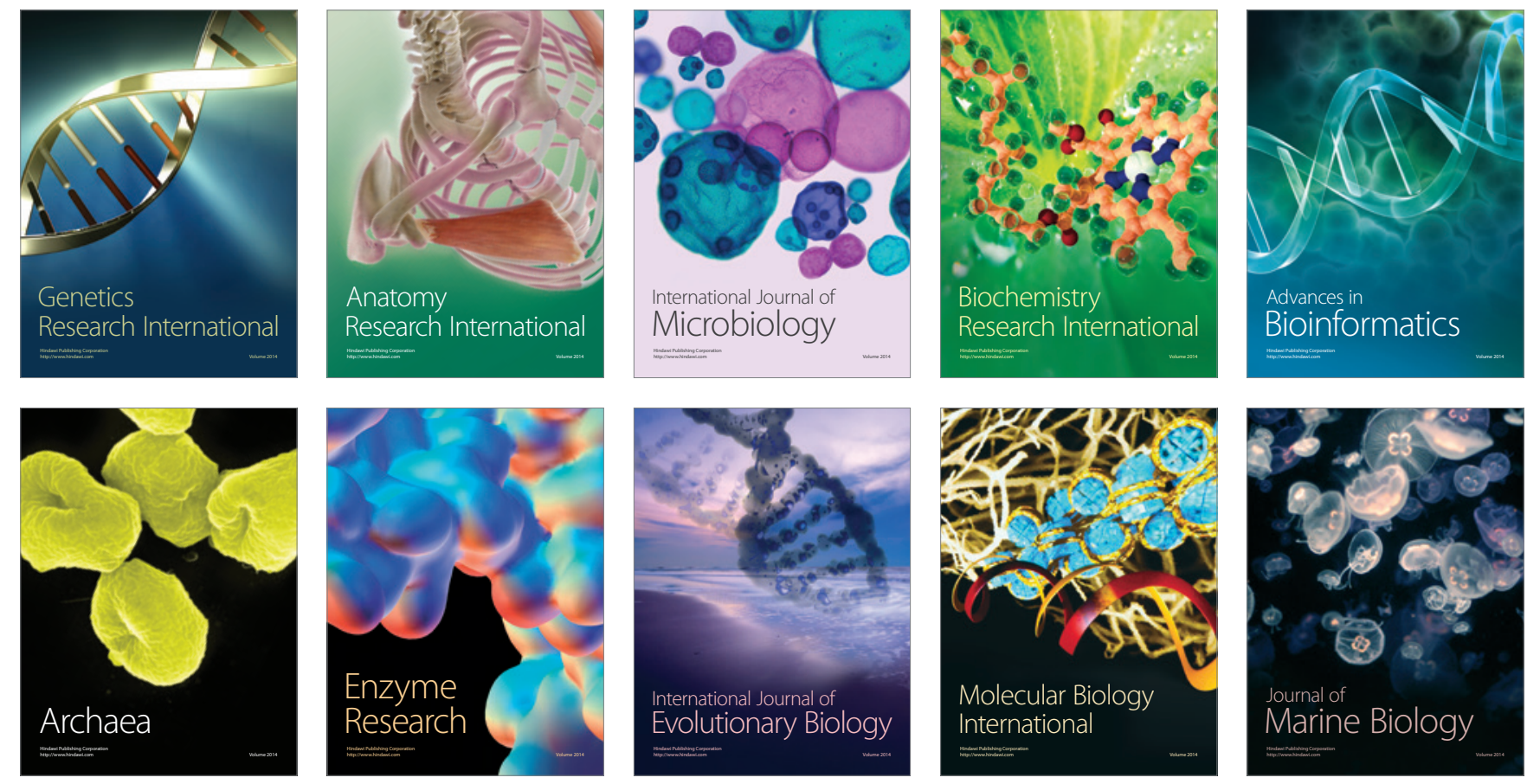